\title{
$\gamma \delta$ T Cell Receptor Analysis Supports a Role for HSP 70 Selection of Lymphocytes in Multiple Sclerosis Lesions
}

\author{
Luca Battistini, ${ }^{\star \dagger}$ Marco Salvetti, ${ }^{\dagger}$ Giovanni Ristori, ${ }^{\dagger}$ \\ Marika Falcone, ${ }^{\dagger}$ Cedric S. Raine, ${ }^{* \neq \$}$ and Celia F. Brosnan* ${ }^{* \neq}$ \\ Departments of *Pathology, ${ }^{\ddagger}$ Neuroscience, and ${ }^{\S}$ Neurology, \\ Albert Einstein College of Medicine, Bronx, New York, U.S.A. \\ 'I Clinica Neurologica, Universita "La Sapienza", Rome, Italy
}

\begin{abstract}
Background: Interactions between $\gamma \delta \mathrm{T}$ cells and heat shock proteins (HSP) have been proposed as contributing factors in a number of diseases of possible autoimmune etiology but definitive evidence to support this hypothesis has been lacking. In multiple sclerosis (MS), a chronic inflammatory neurologic disease, HSP and $\gamma \delta \mathrm{T}$ cells are known to colocalize in brain lesions. Analysis of $\mathrm{T}$ cell receptor (TCR) gene usage in these lesions has detected evidence of clonality within both the V $\delta 2-\mathrm{J} \delta 1$ and $\mathrm{V} \delta 2-\mathrm{J} \delta 3$ populations of $\gamma \delta \mathrm{T}$ cells. In our own studies, using direct sequence analysis, a dominant $\mathrm{V} \delta 2-\mathrm{J} \delta 3$ TCR sequence was found in 9 MS brain samples, suggesting a response to a common antigen. In this report, we have examined $\gamma \delta \mathrm{T}$ cell receptor gene usage in MS peripheral blood $\mathrm{T}$ cell lines selected for reactivity to HSP 70.

Materials and Methods: TCR rearrangement patterns for $\mathrm{V} \delta 2-\mathrm{J} \delta 1$ and $\mathrm{V} \delta 2-\mathrm{J} \delta 3$ were studied using the polymerase chain reaction (PCR) and a direct sequencing technique in populations of peripheral blood mononuclear cells (PBMC) cultured with Mycobacterium tuberculosis (M. tuberculosis) purified protein derivative (PPD) and then selected for reactivity to a $70-\mathrm{kD}$ heat shock protein (HSP70). Cells were obtained from healthy donors, patients with MS, and patients with tuberculosis (TB). PCR products were subjected to direct sequence analysis to
\end{abstract}

look for evidence of clonality within these $\mathrm{T}$ cell lines and to define the sequence of the V-D-J (CDR3) region of the TCR.

Results: In freshly isolated PBMC, both V $\delta 2-\mathrm{J} \delta 1$ and $\mathrm{V} \delta 2-\mathrm{J} \delta 3$ gene rearrangement patterns were detected, whereas in $\mathrm{HSP70}^{+} \mathrm{T}$ cell lines the predominant $\delta$ chain rearrangement pattern was $\mathrm{V} \delta 2-\mathrm{J} \delta 3$. Direct sequence analyses indicated that in cells reactive with HSP70 the $\mathrm{V} \delta 2-\mathrm{J} \delta 3$ sequences were usually oligoclonal and used $\mathrm{D} \delta 3$ exclusively. In four of four MS and two of three TB patients, the oligoclonal sequences in the $\mathrm{HSP}^{+}{ }^{+} \mathrm{T}$ cell lines were identical to one another and to a dominant sequence previously detected in MS brain lesions. In two of three $\mathrm{HSP}^{+} \mathrm{T}^{+} \mathrm{T}$ cell lines from healthy controls, the oligoclonal sequences differed from those found in both groups of patients but were identical to one another except for a small region of heterogeneity in the second $\mathrm{N}$ region. In contrast, in freshly isolated PBMC or in $\mathrm{PPD}^{+} \mathrm{HSP70}^{-} \mathrm{T}$ cell lines, the $\mathrm{V} \delta 2-\mathrm{J} \delta 3$ gene rearrangement patterns were usually polyclonal and dominant sequences were rarely identified.

Conclusions: These results support the conclusion that a subpopulation of $\gamma \delta \mathrm{T}$ cells in MS lesions are responding to HSP 70 and that non-CNS-specific antigens contribute to the pathogenesis of MS.

\section{INTRODUCTION}

Multiple sclerosis (MS) is a chronic debilitating disease of young adults in which the central nervous system (CNS) becomes the site of an im-

Address correspondence and reprint requests to: Celia Brosnan, Department of Pathology, Albert Einstein College of Medicine, 1300 Morris Park Avenue, Bronx, NY 10461. mune attack upon the insulating membrane of nerve fibers, myelin, which is selectively destroyed. While the focus of attention in MS has traditionally been on $\mathrm{T}$ cell responses to components of the myelin sheath, evidence is emerging to suggest that non-CNS-specific antigens may play a contributory role, particularly at later stages of the disease. Among these antigens are 
the heat shock proteins (HSP), some members of which are known to be strongly immunogenic, conserved across the evolutionary tree, and expressed following exposure to a wide variety of stressors including heat shock and inflammatory mediators (1). Among T cell subsets thought to recognize these antigens are lymphocytes bearing the $\gamma \delta \mathrm{T}$ cell receptor (TCR).

$\gamma \delta \mathrm{T}$ cells are a minor population of peripheral blood lymphocytes whose exact function remains unclear. In this group of $\mathrm{T}$ cells, the repertoire of the $\mathrm{V}, \mathrm{D}$, and $\mathrm{J}$ region genes has been shown to be limited and junctional diversity is achieved by template and non-template-derived nucleotide insertions in the CDR3 region $(2,3)$. In some tissues, especially in the mouse, $\gamma \delta \mathrm{T}$ cells have been shown to express invariant TCR gene usage, suggesting a response to highly conserved antigenic sequences (3). At birth, most $\gamma \delta$ $\mathrm{T}$ cells in the peripheral blood and thymus express $\mathrm{V} \delta 1$; however, postnatally the $\mathrm{V} \delta 2$ cells expand, and in the adult $\mathrm{V} \delta 2 / \mathrm{V} \gamma 2(\mathrm{~V} \gamma 9)$ gene segments are expressed by $>70 \%$ of circulating $\gamma \delta$ T cells $(4,5)$. These V $\delta 2$ cells also express high levels of CD45RO, a marker for memory T cells, suggesting expansion following exposure to foreign antigens or superantigens (5). Consistent with this hypothesis are the observations that $\mathrm{V} \delta 2$ - $\mathrm{V} \gamma 2$-expressing $\mathrm{T}$ cells are selectively expanded following exposure to mycobacterial antigens $(6-8)$. Further studies of the $\gamma \delta \mathrm{T}$ cell response to mycobacteria have suggested that members of the HSP $65-$ and $70-\mathrm{kD}$ families may represent immunodominant antigens, although selective expansion of $\mathrm{V} \delta 2$ cells in response to mycobacteria-associated superantigens has also been demonstrated (9-13). Mycobacterial HSP 65 and HSP 70 show significant sequence homology with the mammalian HSP 60 and HSP 70 families and the expression of HSP by stressed autologous host cells has implicated a role for immune responses against HSP in diseases of possible autoimmune etiology $(9,14)$. In MS, several studies have suggested the presence of amplified reactivity to recombinant HSP and/or mycobacterial antigens (15-19). The clearest data exist for responses to HSP70, where the relative frequency of $\mathrm{HSP} 70$-reactive $\mathrm{T}$ cell lines (17) or $\gamma \delta \mathrm{T}$ cell clones (18) was found to be significantly increased in peripheral lymphocytes from MS patients compared with healthy donors, patients with $\mathrm{TB}$, and patients with other neurological diseases. $\gamma \delta \mathrm{T}$ cells have been localized in demyelinated MS lesions, coincident with in- creased immunoreactivity for several HSP, suggesting possible functional associations $(20,21)$.

In an attempt to detect the presence of an antigen-driven response within $\gamma \delta \mathrm{T}$ cells in MS tissues, several groups have examined TCR gene usage by sequencing and cloning polymerase chain reaction (PCR) products. The results of these studies have shown that, while in the acute stage of the disease $\mathrm{V} \delta \mathrm{I}^{+}$cells accumulate in the CSF and perivascular cuffs, in more chronic stages $\mathrm{V} \delta 2^{+}$cells predominate in demyelinated lesions (20-23). Cloning and sequencing of the PCR products have suggested the presence of clonal expansion in both the V $\delta 2-\mathrm{J} \delta 1$ and $\mathrm{V} \delta 2$ $\mathrm{J} \delta 3$ populations of these cells in the lesions, and in $\mathrm{V} \delta 1^{+}$cells in the cerebrospinal fluid (21-24). In our own studies, using direct sequence analysis to assess clonality within MS lesions, the $\mathrm{V} \delta 2-\mathrm{J} \delta 1$ response was found to be polyclonal in eight of nine MS patients, and oligoclonal in one. In contrast, a common dominant V $\delta 2-\mathrm{J} \delta 3 \mathrm{TCR}$ sequence was found in all nine MS brain samples, whereas the response for this gene rearrangement pattern was polyclonal in three other neurological disease patients studied for control purposes (24). These data support the conclusion that at least some $\gamma \delta \mathrm{T}$ cells in MS lesions respond to a common antigen.

In this report, we have used the same direct sequencing technique to assess TCR gene usage in HSP 70 responsive $\mathrm{T}$ cell lines derived from MS patients, tuberculosis (TB) patients, and healthy controls, and have compared the results with those obtained in $\mathrm{T}$ cell lines responding to PPD but nonreactive to HSP 70 . Since the $\gamma \delta$ T cell responses in MS patients showed predominant usage of $\mathrm{V} \delta 2-\mathrm{J} \delta 1$ or $\mathrm{V} \delta 2-\mathrm{J} \delta 3$ (24), and since evidence of clonality within this population of cells can be most clearly defined by analysis of the $\delta$ chain gene (2), we focussed our studies on identification of these TCR rearrangement patterns.

\section{MATERIALS AND METHODS}

\section{Donors}

All tissue samples and in vitro culture procedures were conducted at the 1st Clinica Neurologica, Universita La Sapienza, Rome, Italy, according to protocols approved by the human experimentation committee of that university. Blood samples were drawn from healthy subjects, patients with relapsing-remitting MS, and patients with bacteriologically or histopathologically proven, active 
tuberculosis. Details of the MS patients have been published previously and none had received immunosuppressive therapy for at least 3 months before entering the study (16). The treatment regimen of the TB patients included isonicotinic acid hydrazide ( $5 \mathrm{mg} / \mathrm{kg} /$ day), rifampin (10 mg/kg/day), ethambutol ( $25 \mathrm{mg} / \mathrm{kg} /$ day), and streptomycin ( $1 \mathrm{~g} /$ day for 60 days). None had associated immune deficiencies.

\section{Antigens}

Purified protein derivative (PPD) was obtained from the Statens Serum Institut, Copenhagen, Denmark. The recombinant $M$. tuberculosis HSP 70 was obtained from Dr. Jan van Embden (Bilthoven, The Netherlands) through the UNDP/World Bank/WHO program.

\section{Generation of Lymphocyte Lines}

Antigen-specific $\mathrm{T}$ cell lines were isolated and expanded as described (16). Briefly, peripheral blood mononuclear cells (PBMC) were seeded in $100 \mu \mathrm{l}$ volumes at a density of $2 \times 10^{6} \mathrm{cells} / \mathrm{ml}$ in medium (RPMI plus $2 \mathrm{mM}$ glutamine, 100 units $/ \mathrm{ml}$ penicillin, $100 \mu \mathrm{g} / \mathrm{ml}$ streptomycin, and $5 \%$ heat inactivated pooled $A B$ serum) in the presence of PPD $(10 \mu \mathrm{g} / \mathrm{ml})$ and expanded with 30 units/ml recombinant human IL-2 every 3-4 days for 15 days. Cultures were restimulated with antigen and $1.5 \times 10^{5}$ irradiated (400 grays) autologous PBMC/well every 15 days.

\section{Proliferation Assays}

$\mathrm{T}$ cell lines were screened for their proliferative responses to $M$. tuberculosis HSP 70 at the time of the third restimulation with antigen (approximately 45 days in culture). In all proliferation assays, samples of $2 \times 10^{4}$ cells were placed in culture in duplicate or triplicate with $1.5 \times 10^{5}$ irradiated autologous PBMC/well and HSP 70. After $72 \mathrm{hr}$ in culture, the cells were labeled with $\left[{ }^{3} \mathrm{H}\right]$-thymidine $(0.5 \mu \mathrm{Ci} /$ well $)$ and harvested 16 $\mathrm{hr}$ later. A stimulation index of $>2$ with a $\Delta \mathrm{cpm}$ $>500$ was regarded as a positive response.

\section{RNA and CDNA Isolation}

Total RNA was extracted from at least $2 \times 10^{6}$ cells using the Chomczynski guanidinium-thiocyanate method. First strand cDNA was synthesized from $5 \mu \mathrm{g}$ of total RNA in the presence of oligo-dT primers and AMV-reverse transcriptase
(Perkin Elmer Cetus, Emeryville, CA, U.S.A.). PCR amplification was performed using $5 \mathrm{U}$ Taq polymerase in $100 \mu$ l reaction mixture containing $10 \mathrm{mM}$ Tris- $\mathrm{HCl} \mathrm{pH} \mathrm{8.3,50} \mathrm{mM} \mathrm{KCl}, 2 \mathrm{mM}$ $\mathrm{MgCl}_{2}, 2 \%$ of the cDNA obtained from $5 \mu \mathrm{g}$ of total RNA, and $1.0 \mathrm{mM}$ of dATP, dCTP, dGTP, and dTTP. The cDNA amplification was performed for 30 cycles. Each cycle included denaturation at $94^{\circ} \mathrm{C}$ for $1 \mathrm{~min}$, annealing at $55^{\circ} \mathrm{C}$ for $2 \mathrm{~min}$ and elongation at $72^{\circ} \mathrm{C}$ for 2 min with an extra cycle of $10 \mathrm{~min}$ at $72^{\circ} \mathrm{C}$. Following amplification, the samples were separated on a $1 \%$ agarose gel. Twenty picomolar of each of the following primers were used: $V \delta 25^{\prime}$ ACCCTCAGGTGCTCCATGAA $3^{\prime} ; \mathrm{J} \delta 1$ 3 $^{\prime}$ TCCACAGTCACACGGGTTC 5'; and J $\delta 33^{\prime}$ TCCACGAAGAGTTTGATGCC $5^{\prime}$. To rule out the possibility that the nucleotide sequence that we obtained was affected by the primers used, we performed similar experiments with the following internal primers: V $\delta 2$ 5' GCACCATCAGAGAGAGATAAGGG 3' and $\mathrm{J} \delta 3$ 3' AAAACATCTGTCGGGTGTCCC 5'. Primers for $\beta$-actin were used as a positive control. The restriction site for V $\delta 2$ was SAL-I and for $J \delta 1$ and $J \delta 3$ was ECO-R1. Details of primer preparation and use, including verification by sequencing and cloning the PCR products, have been reported previously (11).

\section{Direct Sequencing}

Direct sequencing was performed from the PCR product according to previously described protocols (24). DNA was purified by isopropanol precipitation to remove excess primer and the DNA was sequenced using a modified Sanger method based on asymmetrical amplification using a primer labeled with $\left[\gamma^{32} \mathrm{P}\right]$ ATP with high specific radioactivity $(5000 \mathrm{Ci} / \mathrm{mmol}, 10 \mathrm{mCi} / \mathrm{ml})$ and sequencing reagents from GIBCO-BRL (Gaithersburg, MD, U.S.A.).

\section{RESULTS AND DISCUSSION}

The results of the PCR analysis and direct sequencing are shown in Fig. 1 and Table 1 . They indicate that, in freshly isolated PBMC, both $\mathrm{V} \delta 2-\mathrm{J} \delta 1$ and $\mathrm{V} \delta 2-\mathrm{J} \delta 3$ gene rearrangement patterns were detected. In contrast, in the PPD ${ }^{+}$HSP $70^{+} \mathrm{T}$ cell lines, the $\mathrm{V} \delta 2-\mathrm{J} \delta 3$ gene rearrangement pattern predominated with only one $\mathrm{T}$ cell line expressing both $\mathrm{V} \delta 2-\mathrm{J} \delta 3$ and $\mathrm{V} \delta 2-\mathrm{J} \delta 1$. Examples of the PCR analysis for $\mathrm{V} \delta 2-\mathrm{J} \delta 1, \mathrm{~V} \delta 2-\mathrm{J} \delta 3$, and $\beta$-actin in the $\mathrm{PPD}^{+} \mathrm{HSP} 70^{+} \mathrm{T}$ cell lines estab- 

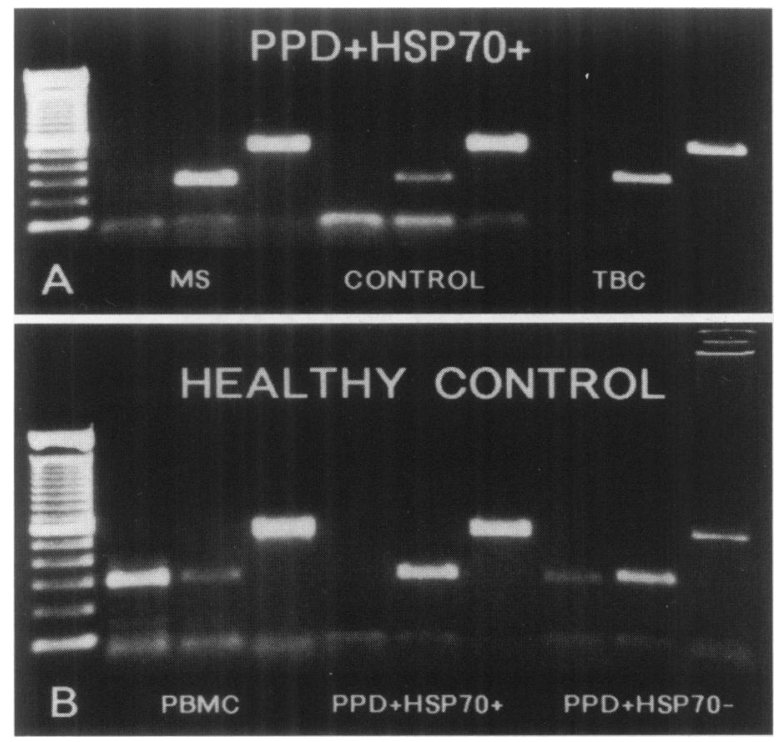

FIG. 1. PCR analysis of $V \delta 2-J \delta 1$ and $V \delta 2-J \delta 3$ in freshly isolated PBMC, or in cells cultured with PPD and selected for reactivity to HSP70

In Panel A, lanes from the left contain molecular weight markers followed by PCR analysis for V $\delta 2$ $\mathrm{J} \delta 1, \mathrm{~V} \delta 2-\mathrm{J} \delta 3$, and $\beta$-actin for one MS patient, one healthy control, and one TB patient, respectively, for $\mathrm{PPD}^{+} \mathrm{HSP}^{+}{ }^{+} \mathrm{T}$ cell lines. In Panel B, lanes from the left contain molecular weight markers followed by PCR analysis for one healthy control for V $\delta 2-J \delta 1$, $\mathrm{V} \delta 2-\mathrm{J} \delta 3$, and $\beta$-actin for freshly isolated PBMC cultured alone, $\mathrm{PPD}^{+} \mathrm{HSP}^{+}$and $\mathrm{PPD}^{+} \mathrm{HSP}^{-} \mathrm{T}$ cell lines. lished from one MS patient, one healthy control, and one TB patient are shown in Fig. 1A. The PCR analyses for $\mathrm{V} \delta 2-\mathrm{J} \delta 1, \mathrm{~V} \delta 2-\mathrm{J} \delta 3$, and $\beta$-actin for freshly isolated PBMC, and $\mathrm{PPD}^{+} \mathrm{T}$ cell lines reactive or nonreactive for HSP 70 from one healthy control are shown in Fig. 1B.

To determine whether clonality occurred within the $V \delta 2-J \delta 3$ gene rearrangement patterns in these $\mathrm{T}$ cell lines, the PCR products were subjected to direct sequence analysis. The advantage of this sequencing strategy for TCR analysis is that conserved sequences can be observed as dominant nucleotides, distinguishable from the nucleotide diversity associated with multiple transcripts. Examples of direct sequence analyses for the V $\delta 2-J \delta 3$ PCR products are shown in Fig. 2. Analyses for the freshly isolated $P B M C$, and the HSP $70^{+}$and HSP $70^{-} \mathrm{T}$ cell lines for one healthy control are shown in the upper panel of Fig. 2, and for freshly isolated PBMC and a HSP $70^{+} \mathrm{T}$ cell line from one TB patient, and a HSP $70^{+}$and HSP $70^{-} \mathrm{T}$ cell line from one MS patient are shown in the bottom panel of Fig. 2. As can be seen in this figure, direct sequences derived from the HSP $70^{+} \mathrm{T}$ cell lines were remarkable for the clarity with which the sequences could be read throughout the junctional region, suggesting oligoclonality within this TCR gene population. In contrast, the direct sequences of the HSP $70^{-} \mathrm{T}$ cell lines, like the freshly isolated PBMC,

TABLE 1. PCR and direct sequence analyses of cell lines ${ }^{a}$

\begin{tabular}{|c|c|c|c|c|c|c|}
\hline \multirow[b]{2}{*}{ Sample } & \multicolumn{2}{|c|}{ PBMC } & \multicolumn{2}{|c|}{ PPD $^{+} \mathrm{HSP}^{+}$} & \multicolumn{2}{|c|}{ PPD $^{+}$HSP70 $^{-}$} \\
\hline & V82-J $\delta 3$ & 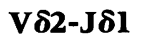 & V82-J83 & V反2-J $\delta 1$ & V $\delta 2-J \delta 3$ & 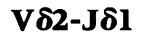 \\
\hline MS \# 1 & $+/ \mathrm{P}$ & + & $+10^{*}$ & - & - & - \\
\hline MS \#2 & - & + & $+10^{*}$ & + & $+/ \mathrm{P}$ & - \\
\hline MS \#3 & $+/ \mathrm{P}$ & + & $+10^{*}$ & - & - & + \\
\hline MS \#4 & $+/ \mathrm{P}$ & nd & $+10^{*}$ & - & na & na \\
\hline TB \# 1 & na & na & +10 & - & +10 & + \\
\hline TB \#2 & $+/ \mathrm{P}$ & + & $+/ \mathrm{O}^{*}$ & - & $+/ \mathrm{P}$ & - \\
\hline TB \#3 & $+/ \mathrm{P}$ & na & $+10^{*}$ & - & $+/ \mathrm{P}$ & - \\
\hline CON \# 1 & $+/ \mathrm{P}$ & + & $+1 \mathrm{O}^{* *}$ & - & + & + \\
\hline $\mathrm{CON} \# 2$ & $+/ \mathrm{P}$ & + & $+1 \mathrm{O}^{* *}$ & - & $+/ \mathrm{P}$ & + \\
\hline $\mathrm{CON} \# 3$ & - & + & - & - & - & - \\
\hline
\end{tabular}

${ }^{a}$ Presence or absence of bands following PCR analyses for the defined V-J genes are marked by a + and - respectively. Direct sequence analyses were defined as polyclonal $(\mathrm{P})$ or oligoclonal $(\mathrm{O})$, with asterisks marking similarities in the oligoclonal sequences. na, not available; nd, not done. 


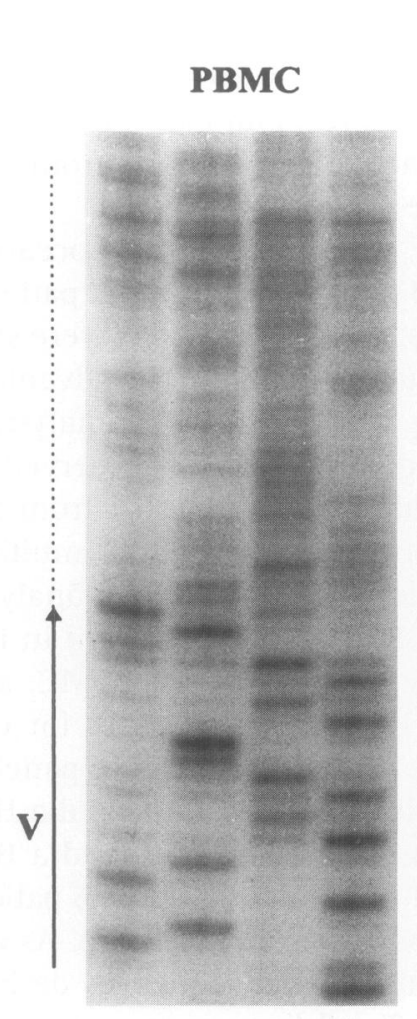

$\begin{array}{llll}\mathbf{A} & \mathbf{C} & \mathbf{G} & \mathbf{T}\end{array}$

\section{HEALTHY CONTROL}

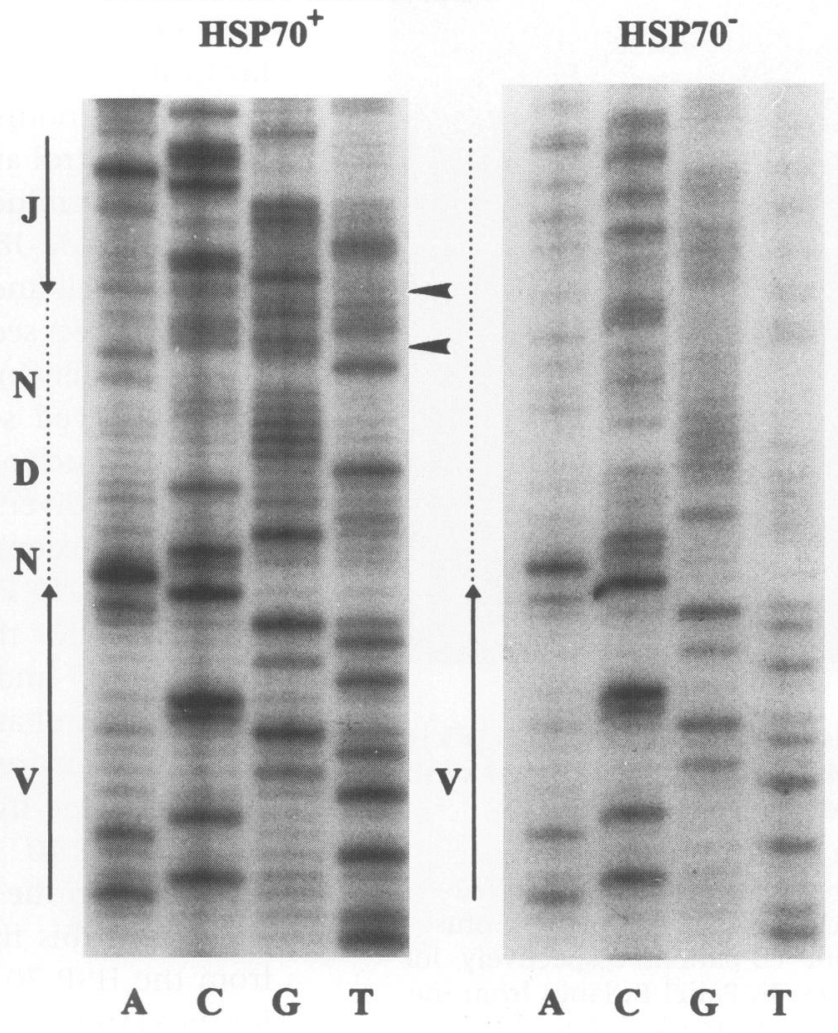

TB

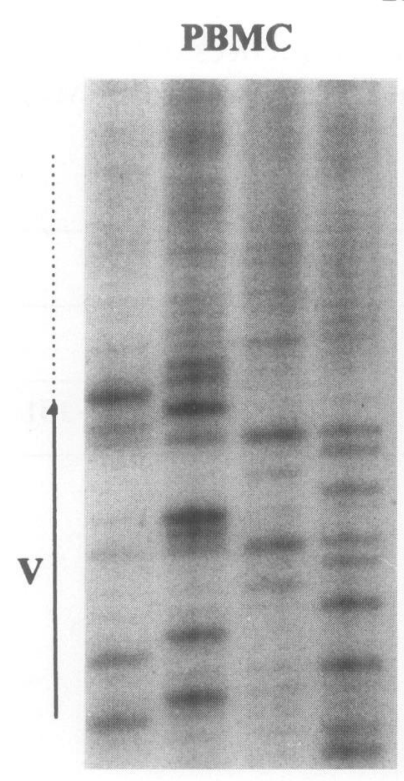

$\begin{array}{llll}\mathbf{A} & \mathbf{C} & \mathbf{G} & \mathbf{T}\end{array}$
HSP70 +

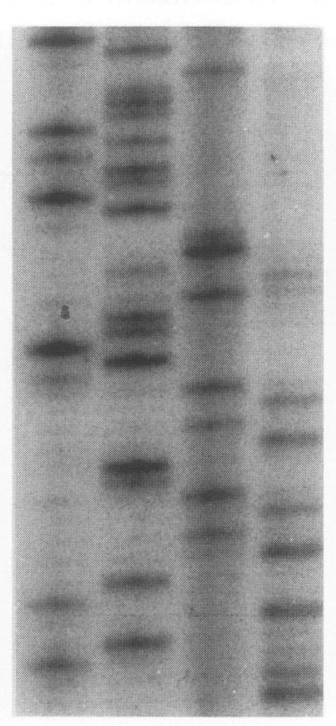

$\begin{array}{llll}\mathbf{A} & \mathbf{C} & \mathbf{G} & \mathbf{T}\end{array}$

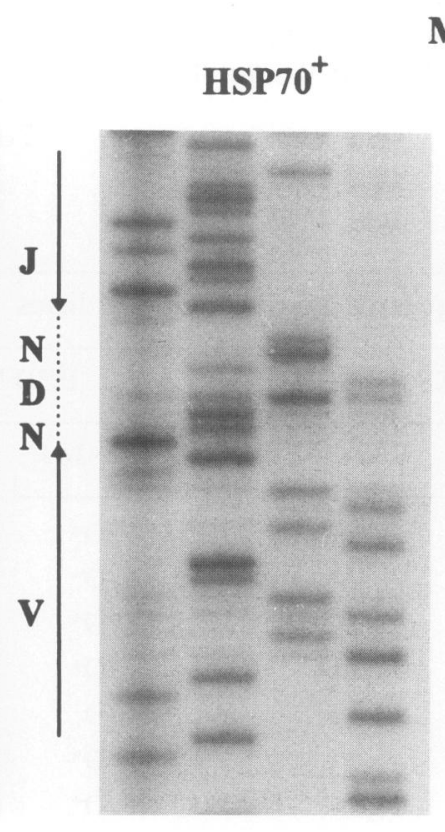

$\begin{array}{llll}\mathbf{A} & \mathbf{C} & \mathbf{G} & \mathbf{T}\end{array}$

MS

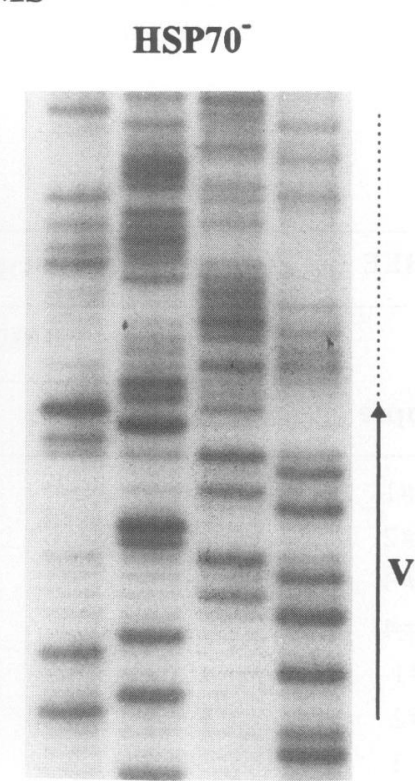

$\begin{array}{llll}\mathbf{A} & \mathbf{C} & \mathbf{G} & \mathbf{T}\end{array}$

FIG. 2. Direct sequence analysis of PCR products for V $\mathrm{V2}-\mathrm{J} \delta 3$

(Upper panel) Direct sequence analyses for V $\delta 2-J \delta 3$ PCR products from one healthy control for freshly isolated PBMC, PPD ${ }^{+} \mathrm{HSP}_{70}{ }^{+}$and $\mathrm{PPD}^{+} \mathrm{HSP70}^{-} \mathrm{T}$ cell lines are shown. (Lower panel) Direct sequence analyses for V $\delta 2-$ J $\delta 3$ PCR products from one TB patient for freshly isolated PBMC and $\mathrm{PPD}^{+} \mathrm{HSP}^{+} \mathrm{T}^{+} \mathrm{T}$ cell lines, and from one MS patient for $\mathrm{PPD}^{+} \mathrm{HSP}^{+}$and $\mathrm{PPD}^{+} \mathrm{HSP}^{-}{ }^{-} \mathrm{T}$ cell lines are shown. 
TABLE 2. Nucleotide and deduced amino acid sequences detected by direct sequencing

\begin{tabular}{|c|c|c|c|c|c|}
\hline Sample & V 82 & $\mathbf{P} / \mathbf{N}$ & $\mathbf{D} \boldsymbol{\delta}$ & $\mathbf{N}$ & $\mathbf{J} \boldsymbol{\delta} \mathbf{3}$ \\
\hline \multirow[t]{4}{*}{ germ-line } & TGT GAC ACC & & & & C TCC TGG GAC AC \\
\hline & & & $\delta 1$ GAAATAGT & & \\
\hline & & & $\delta 2$ ССТТССТАС & & \\
\hline & & & $\delta 3$ ACTGGGGGATACG & & \\
\hline \multicolumn{6}{|l|}{$\mathrm{PPD}^{+} \mathrm{HSP}^{+} 0^{+}$} \\
\hline \multirow[t]{2}{*}{ CONT \#1\#2 } & TGT GAC ACC & GTG & CTG GGG GAT ACG & NNN G & CC TGG GAC AC \\
\hline & C D T & $\mathrm{V}$ & L G D T & $(*)$ & A W D T \\
\hline \multicolumn{6}{|l|}{$\mathrm{PPD}^{+} \mathrm{HSP}^{+} 0^{+}$} \\
\hline MS \#1,2,3,4 & TGT GAC ACC & GTC & GGA & CAC C & $\mathrm{AC} \mathrm{AC}$ \\
\hline TB \#2, \#3 & $\mathrm{CDT}$ & $\mathrm{V}$ & G & $\mathrm{H}$ & $\mathrm{H} \mathrm{T}$ \\
\hline $\mathrm{PPD}^{+} \mathrm{HSP}^{+} 0^{+}$ & TGT GAC A & GC CGT & TGG G & CA CAC GCA & TCC TGG GAC AC \\
\hline TB \# 1 & C D & S R & $\mathrm{W}$ & A H A & S W D T \\
\hline $\mathrm{PPD}^{+} \mathrm{HSP}^{-} 0^{-}$ & TGT GAC ACC & G & CT GGG GGG & CG & C TCC TGG GAC AC \\
\hline TB \# 1 & C D T & & A G G & $\mathbf{R}$ & S W D T \\
\hline
\end{tabular}

V $\delta 2-J \delta 3$ junctional sequences from direct sequence gels of PCR products from freshly isolated PBMC or cells cultured with PPD and tested for reactivity to HSP70. Sequences obtained from HSP70 ${ }^{+} \mathrm{T}$ cell lines from controls 1 and 2 differed from one another by only a short region of heterogeneity. Sequences obtained from HSP70 ${ }^{+} \mathrm{T}$ cell lines from MS patients 2,3 and 4, and TB patients 2 and 3 were identical. Sequences obtained from an $\mathrm{HSP}^{+}$and an $\mathrm{HSP}^{-}{ }^{-} \mathrm{T}$ cell line from one TB patient were oligoclonal but differed from all other sequences.

became unreadable at the end of the $V \delta 2$ sequence and the beginning of the junctional region, indicating the heterogeneity of the transcripts to be expected in the putative CDR3 region of a polyclonal $\mathrm{T}$ cell population. The dominant sequences identified in the $\mathrm{V} \delta 2-\mathrm{J} \delta 3$ transcripts, along with the deduced amino acid sequences, are shown in Table 2 . All dominant sequences were in frame, displayed portions of the D $\delta 3$ gene segment, and predominantly used the palindromic $G$ at the beginning of the junctional region.

The dominant sequences fell into three groups. In controls 1 and 2, the oligoclonal sequences in the HSP $70^{+} \mathrm{T}$ cell lines were different from those detected in the patients, but were identical to one another except for a small region of microheterogeneity present in the second $\mathrm{N}$ region between the D $\delta 3$ and $J \delta 3$ segments (arrows in Fig. 2, top panel). In four of four MS and two of three TB patients, the dominant $\mathrm{V} \delta 2-\mathrm{J} \delta 3$ sequences detected in the HSP $70^{+} \mathrm{T}$ cell lines were identical to one another and to a dominant sequence previously detected in MS brain tissues (24). In the remaining TB patient, the oligoclonal patterns for both the HSP $70^{+}$and HSP $70^{-} \mathrm{T}$ cell lines were different from all of the others. In the two controls, the LGDT sequence in the junctional region represents the second reading frame of $D \delta 3$, whereas in the patients there was a shift to an abbreviated use of the third reading frame of $D \delta 3$. Most dominant sequences also expressed the strongly hydrophobic valine at position 97 of the $\delta$ chain (25). Frequent usage of this amino acid (or less often Leu or Ile) at this position in $\mathrm{T}$ cells using the V $\delta 2$ gene has been extensively documented $(11,23,26,27)$, particularly in cells expressing $\mathrm{V} \delta 2-\mathrm{V} \gamma 2$ gene segments. The expression of this amino acid at this position has been shown to be coded by template-independent $\mathrm{N}$ nucleotides and not to be due to pairing constraints (26), suggesting an antigendriven selection process.

The preferential use of the downstream $\mathrm{D} \delta 3$ element in subpopulations of $\gamma \delta \mathrm{T}$ cells has also been noted previously. In fetal thymic and liver development, the $D \delta 3$ gene is used almost exclusively $(5,28)$, and repeated use of $\mathrm{D} \delta 3$ has been noted in ${\mathrm{V} \delta 2^{+}}^{+}$cells in human leishmaniasis lesions (29) and in cells cultured from jejunic and colonic biopsies from healthy individuals (30). Interestingly, in the latter study, frequent rear- 
rangement to $\mathrm{J} \delta 3$ was also noted, as has been found in fetal liver $\gamma \delta \mathrm{T}$ cells (28). In the adult, although $\mathrm{V} \delta 2$ is found on the majority of peripheral blood $\gamma \delta \mathrm{T}$ cells, rearrangement to $\mathrm{J} \delta 3$ is relatively rare and $\mathrm{J} \delta 1$ is preferentially used. However, it has been noted that peripheral blood V $\delta 2$ junctions often display greater usage of both $\mathrm{D} \delta 3$ and $\mathrm{J} \delta 3$, and fewer $\mathrm{N}$ nucleotide incorporations than $\mathrm{V} \delta 1$ expressing $\mathrm{T}$ cells $(2,3)$.

The above results support the conclusion that HSP 70 selects for an oligoclonal response within the $V \delta 2-J \delta 3$ population, but whether this represents direct responsiveness to HSP 70 cannot be determined from the present culture conditions. Although some studies have documented a proliferative response of $\gamma \delta \mathrm{T}$ cells to HSP $(9,18)$, others have suggested that these cells expand in response to activation markers or growth factors associated with $\mathrm{T}$ or $\mathrm{B}$ cell responses, as for example in the polyclonal activation of ${\mathrm{V} \delta 1^{+}}^{+}$cells to EBV-transformed or activated $B$ cells (31). However, the results of the direct sequencing technique provide compelling evidence for a specific selection process in cells responding to HSP 70 . Whereas the sequences in the freshly isolated PBMC or $\mathrm{PPD}^{+} \mathrm{HSP} 70^{-}$ V $\delta 2-J \delta 3$ population became unreadable at the end of $\mathrm{V} \delta 2$, indicating the variability to be expected in the junctional region, HSP $70^{+} \mathrm{T}$ cell lines expressed a dominant sequence that was clearly readable throughout the V-D-J region. Oligoclonal expansion of $\gamma \delta \mathrm{T}$ cells has been noted in a number of pathologic conditions including skin lesions in patients with sarcoidosis (32), leprosy (33), and American leishmaniasis (29); in the joints of patients with rheumatoid arthritis (34), in MS lesions $(21,22,24)$, and in one case of polymyositis in which, like our present findings, there was an oligoclonal response in a $\mathrm{V} \delta 2-\mathrm{J} \delta 3$ population (35). Interestingly, frequent exclusive recombination of $\mathrm{V} \delta 2$ and $D \delta 3$ was also noted in some of these tissues $(24,34,35)$. Although evidence of clonality within the peripheral blood population was not noted in many of these studies, a tendency towards oligoclonality within both the $\mathrm{V} \delta 2$ and $\mathrm{V} \delta 1$ populations has been noted in association with normal aging (36).

A particularly surprising outcome of our studies was the observation that the sequence in four of four MS patients and two of three TB patients was identical to that found in this same subset of $\gamma \delta \mathrm{T}$ cells in MS lesions. These data suggest that in certain chronic inflammatory diseases, an epitope of HSP 70 selects for a specific subpopulation of $\gamma \delta \mathrm{T}$ cells, and supports the conclusion that in MS lesions these cells are responding to HSP 70. Although we can only speculate on the potential relevance of this observation to lesion development, $\gamma \delta \mathrm{T}$ cells are known to possess potent cytotoxic activity and have been demonstrated to kill oligodendrocytes in vitro (37). Alternatively, interaction of $\gamma \delta$ T cells with HSP 70 could function in an immunoregulatory pathway following expression of HSP 70 on the surface of inflammatory cells (38). In active MS lesions, immunoreactivity for HSP has been found on inflammatory cells in the perivascular cuffs and on glial cells at the edge of the lesion $(20,21)$, and cytokines have been shown to upregulate HSP 70 on glial cells in vitro (39). Furthermore, a particular polymorphism of HSP 70 has recently been associated with cellular reactivity to HSP 70 in patients with MS (40). HSP 70 is known to be an immunodominant antigen that contains many stimulatory epitopes. Ongoing studies will determine whether the different oligoclonal sequences detected in the patient and control sample groups represent responses to different epitopes of HSP 70 and whether these reside within conserved or nonconserved regions of the protein.

\section{ACKNOWLEDGMENTS}

Supported in part by USPHS Grants NS 11920 and NS 08952, and RG 1001-H-8 and FA 1095 from the National Multiple Sclerosis Society, the New York Community Trust and the Gladstein Foundation; and by grants from the Italian Multiple Sclerosis Society (AISM) and the Istituto Mediterraneo per la Ricerca Scientifica, Pozzilli, Italy. Presented in part at the IVth International Congress of Neuroimmunology, Amsterdam, The Netherlands, 1994.

\section{REFERENCES}

1. Georgopoulos C, McFarland H. (1993) Heat shock proteins in multiple sclerosis and other autoimmune diseases. Immunol. Today 14: 373-375.

2. Porcelli S, Brenner MR, Band H. (1991) Biology of the human $\gamma \delta$ T-cell receptor. Immunol. Rev. 120: 137-183.

3. Haas W, Pereira P, Tonegawa S. (1993) Gamma/delta T cells. Annu. Rev. Immunol. 11: 637-685. 
4. De Libero G, Casorati G, Giachino C, et al. (1991) Selection by two powerful antigens may account for the presence of the major population of human peripheral gammadelta T cells. J. Exp. Med. 173: 1311-1322.

5. Parker CM, Groh V, Band H, et al. (1990) Evidence for extrathymic changes in the $\mathrm{T}$ cell receptor $\gamma \delta$ repertoire. J. Exp. Med. 171: 1597-1612.

6. Modlin RL, Pirmez C, Hofman FM, et al. (1989) Lymphocytes bearing antigen-specific $\gamma \delta$ T-cell receptors accumulate in human infectious disease lesions. Nature 338: 544-548.

7. Janis EM, Kaufman SHE, Schwartz RH, Pardoll DM. (1989) Activation of $\gamma \delta$ T cells in the primary immune response to Mycobacterium tuberculosis. Science 244: 713-716.

8. Kabelitz D, Bender A, Prospero T, Wesselborg S, Jannsen O, Pechhold K. (1991) The primary response of human $\gamma \delta^{+} \mathrm{T}$ cells to Mycobacterium tuberculosis is restricted to $\mathrm{V} \gamma 9$ bearing cells. J. Exp. Med. 173: 1331-1338.

9. Haregewoin A, Soman G, Hom RC, Finberg RW. (1989) Human $\gamma \delta$ T cells respond to mycobacterial heat shock protein. Nature 340: 309-312.

10. O'Brien RL, Happ MP, Dallas A, Palmer E, Kubo R, Born WK. (1989) Stimulation of a major subset of lymphocytes expressing $\mathrm{T}$ cell receptor gamma delta by an antigen derived from Mycobacterium tuberculosis. Cell 57: 667-674.

11. Ohmen J, Barnes PF, Uyemura K, Lu S, Grisso CL, Modlin RL. (1991) The T cell receptors of human $\gamma \delta \mathrm{T}$ cells reactive to $M y$ cobacterium tuberculosis are encoded by specific $\mathrm{V}$ genes but diverse $\mathrm{V}-\mathrm{J}$ junctions. $J$. Immunol. 147: 3353-3359.

12. Pfeffer K, Schoel B, Plesnila N, et al. (1992) A lectin-binding, protease-resistant, mycobacterial ligand specifically activates $\mathrm{V} \gamma 9^{+}$ human $\gamma \delta$ T cells. J. Immunol. 148: 575-583.

13. Tanaka Y, Sano S, Nieves E, et al. (1994) Non-peptide ligands for $\gamma \delta \mathrm{T}$ cells. Proc. Natl. Acad. Sci. U.S.A. 91: 8175-8179.

14. Rajasekar R, Sim G-K, Augustin A. (1990) Self heat shock and $\gamma \delta \mathrm{T}$ cell reactivity. Proc. Natl. Acad. Sci. U.S.A. 87: 1767-1771.

15. Birnbaum G, Kotilinek L, Albrecht L. (1993) Spinal fluid lymphocytes from a subgroup of multiple sclerosis patients respond to mycobacterial antigens. Ann. Neurol. 34: 18-24.

16. Salvetti $M$, Buttinelli $C$, Ristori $G$, et al. (1992) T lymphocyte reactivity to the myco- bacterial 65 - and 70-kDa heat shock proteins in multiple sclerosis. J. Autoimmun. 5: 691702.

17. Salvetti M, Ristori G, Buttinelli C, et al. (1994) $\mathrm{T}$ Lymphocyte response to $70-\mathrm{kD}$ heat shock proteins in multiple sclerosis, in tuberculosis and in healthy individuals. $J$. Neuroimmunol. 54: 193A.

18. Stinissen $P$, Vandevyer $C$, Medaer $R$, et al. (1995) Increased frequency of $\gamma \delta \mathrm{T}$ cells in CSF and peripheral blood of MS patients: Reactivity, cytotoxicity and $\mathrm{T}$ cell receptor $\mathrm{V}$ gene rearrangements. J. Immunol. 154: 4883-4894.

19. van Noort JM, van Sechel AC, El Ouagmiri $\mathrm{M}$, Bajramovic J, Polman $\mathrm{CH}$, Ravid R. (1994) A small heat shock protein serves as immunodominant T-cell antigen in MS-affected human myelin. J. Neuroimmunol. 54: 194A.

20. Selmaj K, Brosnan CF, Raine CS. (1991) Colocalization of lymphocytes bearing $\gamma \delta \mathrm{T}$-cell receptor and heat shock protein hsp $65^{+}$oligodendrocytes in multiple sclerosis. Proc. Natl. Acad. Sci. U.S.A. 88: 6452-6456.

21. Wucherpfennig KW, Newcombe J, Li H, Keddy C, Cuzner ML, Hafler DA. (1992) $\gamma \delta$ T-cell receptor repertoire in acute multiple sclerosis lesions. Proc. Natl. Acad. Sci. U.S.A. 89: 4588-4592.

22. Shimonkevitz R, Colburn C, Burnham JA, Murray RS, Kotzin BL. (1993) Clonal expansion of activated $\gamma / \delta$ T cells in recent onset multiple sclerosis. Proc. Natl. Acad. Sci. U.S.A. 90: 923-927.

23. Hvas J, Oksenberg JR, Fernando R, Steinman L, Bernard CCA. (1993) $\gamma \delta$ T cell receptor repertoire in brain lesions of patients with multiple sclerosis. J. Neuroimmunol. 46: 225-234.

24. Battistini L, Selmaj K, Kowal C, et al. (1995) Multiple sclerosis: Limited diversity of the V $\delta 2-J \delta 3$ T-cell receptor in chronic active lesions. Ann. Neurol. 37: 198-203.

25. Triebel F, Faure F, Mami-Chouaib F, et al. (1988) A novel $V \delta$ gene expressed predominantly in the Ti $\gamma \mathrm{A}$ fraction of $\gamma / \delta^{+}$peripheral lymphocytes. Eur. J. Immunol. 18: 20212027.

26. Davodeau F, Peyrat MA, Hallet MM, Houde I, Vie H, Bonneville M. (1993) Peripheral selection of antigen receptor junctional features in a major human $\gamma \delta$ subset. Eur. $J$. Immunol. 23: 804-808.

27. Breit TM, Wolvers-Tettero ILM, van Dongen 
JM. (1994) Unique selection determinant in polyclonal $\mathrm{V} \delta 2-\mathrm{J} \delta 1$ junctional regions of human peripheral $\gamma \delta \mathrm{T}$ lymphocytes. J. Immunol. 152: 2860-2864.

28. Wucherpfennig KW, Liao YJ, Prendergast $M$, Prendergast J, Hafler DA, Strominger JL. (1993) Human fetal liver $\gamma \delta$ T cells predominantly use unusual rearrangements of the $\mathrm{T}$ cell receptor $\delta$ and $\gamma$ loci expressed on both CD4+ and CD8- and CD4-CD8- $\gamma \delta \mathrm{T}$ cells. J. Exp. Med. 177: 425-432.

29. Uyemura K, Klotz J, Pirmez C, et al. (1992) Microanatomic clonality of $\gamma \delta \mathrm{T}$ cells in human Leishmaniasis lesions. J. Immunol. 148: 1205-1211.

30. Robijn RJ, Bloemendal H, Jainandunsing $\mathrm{S}$, et al. (1993) Phenotypic and molecular characteristics of human monoclonal TCR $\gamma \delta \mathrm{T}$ cell-lines from jejunum and colon of healthy individuals. Scand. J. Immunol. 38: 247-253.

31. Orsini DLM, van Gils M, Kooy YMC, et al. (1994) Functional and molecular characterization of B cell-responsive $\mathrm{V} \delta \mathrm{l}+\gamma \delta \mathrm{T}$ cells. Eur. J. Immunol. 24: 3199-3204.

32. Tamura N, Holroyd KJ, Banks T, Kirby M, Okayama H, Crystal RG. (1990) Diversity in junctional sequences associated with the common human $\mathrm{V} \gamma 9$ and $\mathrm{V} \delta 2$ gene segments in normal blood and lung compared with the limited diversity in a granulomatous disease. J. Exp. Med. 172: 169-181.

33. Uyemura K, Deans RJ, Band H, et al. (1991) Evidence for clonal selection of $\gamma / \delta \mathrm{T}$ cells in response to a human pathogen. J. Exp. Med. 174: 683-692.

34. Olive C, Gatenby PA, Serjeantson S. (1992) Variable gene usage of $\mathrm{T}$ cell receptor $\gamma$ and $\delta$-chain transcripts expressed in synovia and peripheral blood of patients with rheumatoid arthritis. Clin. Exp. Immuol. 87: 172-177.

35. Pluschke G, Ruegg D, Hohlfeld R, Engel AG. (1992) Autoaggressive myocytotoxic T lymphocytes expressing an unusual gamma/ delta T cell receptor. $J$. Exp. Med. 176: 17851789.

36. Giachino C, Granziero L, Modena V, et al. (1994) Clonal expansion of $\mathrm{V} \delta 1^{+}$and $\mathrm{V} \delta 2^{+}$ cells increase with age and limit the repertoire of human $\gamma \delta \mathrm{T}$ cells. Eur. J. Immunol. 24: 1914-1918.

37. Freedman MS, Ruijs TCG, Selin LK, Antel JP. (1991) Peripheral blood gamma-delta T cells lyse fresh human brain-derived oligodendrocytes. Ann. Neurol. 30: 794-800.

38. Janeway CA, Jones B, Hayday A. (1988) Specificity and function of T cells bearing $\gamma / \delta$ receptors. Immunol. Today 9: 73-76.

39. D'Souza SD, Antel JP, Freedman MS. (1994) Cytokine induction of heat shock protein expression in human oligodendrocytes: An interleukin-1-mediated mechanism. J. Neuroimmunol. 50: 17-24.

40. Freedman MS, Abiscott J, Goldstein R. HSP70 gene polymorphism correlates with cellular reactivity to HSP in multiple sclerosis. Neurology (1995) 45: A467. 